\title{
Sinful enough for Jesus: guilt and Christianisation at Mapoon, Queensland
}

\section{Devin Bowles}

The mission at Mapoon is the site of myriad stories. Many have already been lost to time and more will follow as another generation takes its memories to the grave. The narrative related here is not the only one that might be told. It concerns the missionaries who founded Mapoon and, most importantly for this telling, the Aboriginal people who became Christian while these missionaries were there. There were other Aboriginal people who did not become Christian. Some who stayed did not become Christian; others left permanently. They have other stories to be told another time.

This story is a cyclical one. Someone makes a sacrifice for the Christian God and someone else feels guilty because of it. This guilt leads them, in turn, to suffer in spreading God's Word and the cycle is renewed. Europeans repeated it for generations before bringing it to Australia. It is at this juncture, at the point of the spread of the cycle from Europeans to Aboriginal people - in which Aboriginal Christians redefined moral transgression for themselves - that this paper is focused. At Mapoon, the tremendous increase in the guilt felt by Aboriginal people as a result of a new emphasis on sin led to a remarkable degree of Christianisation, which in turn reinforced the new prominence of moral transgression.

The story is an important one for several reasons. It demonstrates some of the ways Aboriginal people creatively adapted Christianity to their own unique needs. It provides an exception to the general rule that Aboriginal Australians have tended not to adopt Christianity without accompanying cultural devastation. In doing so, it points the way to at least part of the role spirituality played in pre-contact Australia. It also suggests why Moravian missionaries have been so effective in populations normally resistant to conversion - because rather than focusing on intellectual persuasion, they relied on Christianity affecting the emotions of potential converts. Moravian practice was marked by a cult-like devotion to Jesus, and at some missions this may have been decisive. At Mapoon, however, the emotional lever with the greatest strength was making people feel indebted and guilty.

\section{Prologue}

The arrival and departure of the founding missionaries from Cape York Peninsula in Queensland sets this story in time, from 1891 until 1919. However the beginnings of this story stretch through almost 2000 years of European history 
to Jesus' death in a Roman-occupied portion of the Middle East, and are planted firmly in pre-contact Australia.

For hundreds of years, Christianity, and the Judaism it grew from, developed in a context in which people were expected to give their allegiance to a ruler. When someone wronged another citizen, vengeance was to come from the king, not the other citizen. People could plead for his mercy, which he could dispense at will, paralleling the situation in Christianity in which all sins were against God and people must seek his mercy to avoid divine retribution. ${ }^{1}$ As a result of the sociopolitical context in which Christianity developed, it is notable for its emphasis on rules. For instance, the book of Leviticus is composed almost entirely of God's regulations for His people. God's rules are absolute and incontestable; they separate right from wrong, good from evil, and the sacred from the profane. Out of this conception of immutable boundaries comes the notion of sin: the transgression of God's law. The Christian story is one of humanity's sin and redemption. For this reason, transgression occupies a more central place in Christianity than in most other religions.

Aboriginal society before settlement lacked the top-down social and spiritual control that marked the development of Christianity. People negotiated relationships with each other, ancestral beings, and the land in an interactive way. Relationships were always interdependent and reciprocal. Transgressions resulted in imbalance - social, ecological and spiritual - though the separation of these categories is a European one. Boundaries and their transgressions played an entirely different role in traditional Aboriginal spirituality than in Christianity. Deborah Bird Rose argues that in traditional Yarralin spirituality, evil as Europeans know it does not exist. ${ }^{2}$ There are immoral acts, actions which disturb the balance of the world, but not evil. There is no one controlling power; everything is interconnected. There is no punishment from 'on high' for moral transgressions; instead, the result of these acts on the interconnected world is imbalance.

\section{Missionaries' guilt}

Understanding why so many Aboriginal people at Mapoon adopted notions of moral transgression similar to those of the missionaries first requires an examination of the missionaries themselves. To have any comprehension of the importance of Jesus and his suffering and resurrection which bridged a degraded humanity and glorious God, to understand the extent of Jesus' love, and to develop one's own love for Him, all fundamental pursuits in Moravian Christianity, one must start with the knowledge that humans are, at base, sinful. Like many European Christians of the day, the missionaries sought to avoid sin in their own lives and save others from sin, in no small part because of what they believed awaited sinners in the afterlife. This emphasis on sin had important consequences for the missionaries. 
The word guilt has at least two interrelated meanings. The first definition is what a judge looks for in a criminal trial. It is a violation of a law. This idea took on particular significance for the missionaries who believed that God had created a divine Law. No violation could escape His notice, and all people would be called to account during the Judgement. For the missionaries, guilt was having committed a sin. The second definition is closely related; it is the feeling aroused in a person by the knowledge he or she has done wrong. As a result of the missionaries' belief in an omnipotent Judge watching for transgressions of His absolute moral law, they were acutely aware of any of their own transgressions of this law and felt guilty for what they perceived as their guilt. Rev. Nicholas Hey closely associated the two meanings of guilt when he wrote that the missionaries tried to 'impart a sense of guilt or $\sin ^{\prime} .^{3}$

The concept of sin and preoccupation with the feeling of guilt influenced the missionaries' use of this emotion as a lever. For most of the period examined in this article, Nicholas Hey was the senior male missionary and thus had the most influence over the 'official' definition of Christianity. Hey's life was directed by feelings of guilt from a young age. His father, who was unable to fulfil his dream of becoming a missionary, wanted his sons to become missionaries until he died (when Nicholas was 13). His mother had great influence on Nicholas and his siblings. ${ }^{4}$

Arthur Ward's brother, JG, died at Mapoon and Arthur's response was to write a book about the mission. He seems to have obtained much of his information from the missionaries and probably possessed a thorough understanding of their motivations. He writes about Hey's mother, 'She spent hours in prayer for them, and they knew it. She saw that they did not, as was natural, think as she did, and she would have willingly suffered the loss of all things rather than that the soul of one of her children should be lost' ${ }^{5}$ Nicholas rebelled against some of the stricter religious elements of her household, such as not being allowed to dance, and eventually ran away.

But he found he could enjoy nothing. Pleasure was not pleasant. Go where he would, he felt himself encompassed by his mother's prayers, and at last he gave up the struggle to emancipate himself from her influence, returned home, and quietly settled down to the old strict routine. Not that he was satisfied with it. The Puritan air stifled him, and he began to feel the uncomfortable sensation that there was no chance for him because he was not good enough. He took to reading his Bible systematically, in the hope that some good might come of it. ${ }^{6}$

Guilt was clearly one, if not the, motivating factor in Nicholas Hey's young life. His studies eventually convinced him that the fate of his soul had not been predetermined and that salvation was possible. Yet despite his apparent break with the religion of his mother, 'the best theology he ever learnt was taught him 
at his mother's feet'. ${ }^{7}$ That his parents' lessons made their mark is evidenced by the fact that two of his brothers became preachers while the third became a medical missionary. The effects of Nicholas' upbringing lasted well beyond childhood. Years after the mission had been founded, Arthur Ward could still write, 'The home influences are as strong as ever, though it is years since his mother died'. 8

Nicholas Hey's 'home influences' were what kept him behaving as he believed a good Christian ought to behave. Even such core elements of his personality as his devotion to Christianity itself and his general way of thinking can be traced back to his early home: 'If one tries to get at the secret of Nicholas Hey's resourcefulness, his earnest piety, and his broad-minded common sense, one is always led back to the days when the boy of 13 left school to become the bread-winner, and to learn from his mother the importance of little things, and the doctrine of stewardship'. ${ }^{9}$ As a young man, the missionary path was blocked for Nicholas Hey because he had to care for his sick mother, who was largely confined to bed for the last seven years of her life. By the time she died, he no longer had the same desire to become a missionary but he still felt it was his duty. He wrote to the Moravian Mission Board to put his guilt about the matter to rest, believing that he would be rejected because at 24 he was too old and, further, because he was unworthy of the position. He saw his acceptance by the Board as a sign of God's will which he did not dare transgress. ${ }^{10}$

Guilt was an important part of the other missionaries' lives, too. It is striking that Arthur Ward, while attempting to praise the missionaries and work at Mapoon, portrayed Nicholas Hey as being racked by guilt. This indicates that Nicholas Hey was not exceptional and perhaps even fairly similar to Arthur and JG Ward. In a diary by one of the European females at Mapoon, virtually the only discussion of the author's emotions was written every new year in a prayer to be a better person in the coming year. ${ }^{11}$ The missionaries passed along religiously motivated feelings of guilt to Aboriginal people. Many of the Aboriginal people felt as though they sinned against the missionaries when they sinned against God and sinned against God when they sinned against the missionaries.

\section{Passing the guilt}

Prior to the mission, the Aboriginal people at Mapoon were largely free of the feelings of intense guilt that marked the missionaries' faith. Upon their arrival, the missionaries made clear that they were suffering in order to bring the Aboriginal people the Christian message. This created an ongoing imbalance that could not be rectified and a situation likely to cause feelings of guilt and indebtedness among Aboriginal people. It would have been difficult for Aboriginal people to accommodate the feelings generated by the new social 
relations or give these relationships meaning using only their traditional belief systems. The Christianity the missionaries brought with them was, almost by definition, exceptionally well suited to these tasks.

Nicholas Hey writes about the start of the mission: 'Two great difficulties confronted the pioneers at this stage. The first was the language, and the second was the absence of a sense of sin in the native mind'. ${ }^{12}$ The missionaries were keen to 'correct' this 'problem' and tried to

impart a sense of guilt or sin, which is quite foreign to the native mind. They could not see that there was anything wrong in themselves, and even when found out in the very act they said the blame rested with the one who gave them away or discovered their offence. It was a constant battle between darkness and light. ${ }^{13}$

The missionaries endeavoured to pass on their European set of criteria for evaluating behaviour to Aboriginal people.

To the missionaries, Aboriginal 'faults' were not mere differences of belief or custom but absolute moral evils, small but definite victories for the forces of darkness. The missionaries summed up their view of Aboriginal religious beliefs in a report, "II believe in devils" is the first article of their creed". ${ }^{14}$ Aboriginal people at Mapoon, initially at least, did not divide the world into the forces of good and evil and so could not have thought that they were siding with the forces of darkness in believing and acting as their fathers and mothers had taught them. Convincing Aboriginal people that there were two sides in a great spiritual battle and that they were on the evil and losing side, the side of sin, was a necessary step in what the missionaries viewed as a change of allegiances conversion. The missionaries sought to teach the Aboriginal people this division intellectually. Aboriginal people were probably more receptive to it because of the new social relationships and the feelings these generated than because of any logical argument offered by the missionaries.

One of the ways missionaries increased Aboriginal feelings of guilt was by assuming a Christ-like role, visibly suffering (much like Hey's mother) for the sake of other people. Like Christ's, their suffering was obviously of a condescending nature. Their message was this: just as God had to lower himself to and endure a human state to redeem humanity, the missionaries had to bear the crosses of leaving 'civilisation' and living amongst savages to bring the Aboriginal people the Gospel. Christ died to give the redeeming Gospel to all of humanity. The missionaries made clear the insalubriousness of the tropical climate. Like many European Australians of the time, the missionaries believed the tropical climate to be inherently unhealthy, a conception no doubt reinforced by JG Ward's death soon after the start of the mission from malaria. Health problems continued to plague the missionaries almost throughout their time at 
Mapoon. ${ }^{15}$ They were risking, or in JG Ward's case, sacrificing, their lives to save Aboriginal souls, like Christ.

The missionaries' sacrifice was made known to the Aboriginal people at Mapoon, some of whom felt guilty and indebted because of it. Many of the Aboriginal Christians wrote letters to Mrs Ward for her departure. These letters were written on different dates by different people on different types of paper in different places. This and the number of spelling and grammatical errors make it unlikely that any of the missionaries were directly regulating the content, though the writers probably wanted to please Mrs Ward. These letters contain several references to Mrs Ward leaving for her health and having endured bad health for the Aboriginal people. Lena M, for instance, wrote, 'We would like you to stay very much but it would be selfish of us to keep you here when you're always sick and ailing God bless and keep you dear Aunty you were always kind and good to us'. ${ }^{16}$ It would not have been necessary for Aboriginal people to believe the Christian message in order for them to experience feelings of deep guilt and indebtedness. They might well remain undecided as to whether or not the Christian story was true but feel indebted to the missionaries for their sacrifices in bringing it to them. Of course, the mere fact that the missionaries were prepared to make these sacrifices may have added weight to their claims. In any event, the feelings of guilt created a situation in which some Aboriginal people found Christian beliefs useful.

In the minds of some of the Aboriginal people, the line between the missionaries and the newfound God was blurry on some levels. The missionaries were like, but not the same as, God or Jesus. Like Jesus, the missionaries were compared to the shepherd going after the one stray sheep. Mackie, one of Mrs Ward's ex-students, wrote, 'We will always have you in our mind and will never forget your teaching us and bringing us back when we went astray'. ${ }^{17}$ Theresa wrote to Mrs Ward, 'I am writing to tell you Dear Auntie that I am very very sorry that I grief you and God for all the wrongs that I did. But now I am asking God to forgive me for my sins. And now Dear Auntie I ask you to pray for me'. ${ }^{18}$ The new concept of sin was held to be an offence against both God and the missionaries. As though she were a saint, it was believed that Mrs Ward could intercede with God on behalf of the Aboriginal people. It is notable that Theresa wrote that she was asking God for forgiveness as she wrote of repentance in her letter to the missionary. Dolly also believed that Mrs Ward had some special ability to bring Aboriginal people closer to God, 'When I think of Auntie's love I hope it will also bring me nearer Jesus' ${ }^{19}$ Hilda thought Mrs Ward's prayer could bring Aboriginal people closer to God by increasing their love for Him, thereby making them less sinful. She wrote, 'Dear Auntie pray for us so that we may come to love our Saviour more and more'. ${ }^{20}$ 
The parallel between God and the missionaries was important. Aboriginal people developed a relationship with the missionaries that was without precedent in traditional culture. This created a whole new set of emotions. The novel social situation and emotional landscape was difficult to reflect in the Aboriginal people's traditional belief systems. It would have been problematic to accommodate the sustained imbalance of a social debt that could not be repaid in the traditional belief system in which people viewed the universe in terms of interconnection and balance. Traditional Aboriginal beliefs were therefore not well suited to explaining the feelings of guilt that the relationships with the missionaries could generate. However, Aboriginal people had another religious system at their disposal, one they could use to help explain and give meaning to their social environment. In adopting Christian beliefs, they were using a tool that the Europeans brought with them, much as they might have used a metal knife.

Moravian Christianity would have been a very useful tool in this situation, focusing as it did on the suffering of Jesus on the cross. The missionaries would have emphasised this aspect of the Christian story, making Christianity particularly useful to Aboriginal people seeking meaning and explanation in these new circumstances. Gollin describes this Moravian emphasis, 'Since it was essential for the believer to keep the death and suffering of Christ on the Cross before his eyes at all times, the image of Christ became identified almost exclusively with His sufferings, His blood, and His wounds' ${ }^{21}$

Aboriginal people were receptive to this message. Several of the letters from Aboriginal people to Mrs Ward contain references to the 'cruel cross'. The Christian story made clear that Jesus' suffering, like that of the missionaries, was for them. A letter from Meaffra and Annette is illustrative: 'I don't forget when I was a boy you teached me about the love of Christ and how he died on the cruel cross to save us from going to hell'. ${ }^{22}$ Emphasis on the suffering of the Saviour would help explain feelings of guilt. That Aboriginal people chose to emphasise this in their letters buttresses the claim that it was this aspect of Christianity that they were using to help meet their emotional and spiritual needs.

The missionaries brought with them a new set of social relationships and a profound sense of guilt. Many Aboriginal people entered into these new relationships and experienced deep feelings of guilt. To help make sense of the new social structures and feelings, they adopted more or less of the belief system that had coevolved with the social structures and feelings for hundreds of years.

\section{Positive feedback loop of guilt}

Aboriginal adoption of Christianity increased their feelings of guilt, thereby increasing the needs that Christianity was meant to be fulfilling. Guilt was critical 
to a relationship in which the missionaries were viewed as God's messengers to the unknowing and sinful Aboriginal people. This relationship increased Aboriginal acceptance of a moral dichotomy and increased the degree to which Aboriginal people used Christianity as a guide in defining the limits of God's law and what constituted moral behaviour.

Aboriginal acceptance of Christianity increased the imbalance of their relationship with the missionaries. If Aboriginal people felt indebted to the missionaries for their sacrifices when they thought they had come to spread a message of dubious truth value, as well as a new way of life, such feelings would surely have increased when they believed the missionaries brought vitally important spiritual information that saved Aboriginal people from eternal damnation. For their part, the missionaries represented themselves as messengers. As the intermediaries of the Gospel between Jesus and the Aboriginal people at Mapoon, they positioned themselves between God and the Aboriginal people. Aboriginal Christians felt indebted to the missionaries for what they believed to be the salvation of their souls. Such a debt could never be repaid and the missionaries would always be holier than the Aboriginal people. The Christianity guilt produced in turn produced more guilt.

Letters Aboriginal people wrote Mrs Ward are eloquent testimony to the Aboriginal feelings of debt and inferiority. Nearly all of the writers thanked Mrs Ward for coming to teach them about Jesus. One fragmentary letter, whose author is unrecorded, is demonstrative, 'Thank God that he has chosen you to be his messenger and to spread his Gospel to the heathen people at Mapoon and to tell that how our loving Saviour shed his blood on Calvary to save us from going to hell.' The author continues in a vein that is reminiscent of the shepherd analogy, 'And now dear Auntie for many years you have been preaching the Gospel here and have brought many souls to Christ. I also do thank you dear Auntie for bringing me up when I was a girl \& telling me about the love of Christ and bringing my poor wandering soul to Christ' ${ }^{23}$

Aboriginal people were aware of the fact that they had previously been unexposed to Christianity and, according to the missionaries, without Christ's influence. The missionaries' depiction of their presence as a Christ-like sacrifice reinforced this idea. Christ and God were portrayed by the missionaries as being infinitely more moral and powerful than weak and sinful humans. The missionaries' explanation for their presence was to lift up especially weak and especially sinful Aboriginal people to a level closer to, but still below, the European standard. One of the constant themes in the letters to Mrs Ward is the hope that they will meet in heaven. Many of the authors, however, worry that they and other Aboriginal people might not be good enough to enter. Ida wrote, 'We hope if not here on earth to meet you in Heaven, but we know it will be very hard for us as there are many temptations in this world. But through God's 
help we will overcome them, it is only if we look to Him and ask Him for strength'. She concludes, 'I will try my best to be one of those to meet you in Heaven'. ${ }^{24}$ Harry Shadforth echoes this sentiment, 'We hope if not to meet on earth we hope to meet at Jesus' feet that this [sic] if I keep true to the Saviour' ${ }^{25}$ No one expressed any doubt that Mrs Ward would enter heaven when she died.

The Christianity the missionaries brought with them was tied to a particular moral universe and an extensive set of rules for behaviour. In Europe, these ideas evolved in conjunction with one another, and the moral universe was vastly different to the one Aboriginal Australians inhabited before contact. When Aboriginal people at Mapoon made Christianity their own, they also changed the way they viewed morality, even if they did not adopt all or even most of what the missionaries brought with them. Of course their past actions viewed in this new light often failed to measure up. The negotiation of two separate moral universes is exponentially more difficult than the navigation of one. Traditional obligations to relatives for time and resources often conflicted with similar demands by the missionaries. The missionaries were able to increase the weight of their demands because they had some success in portraying themselves as spiritual mediators between Aboriginal people and God. ${ }^{26}$ Ironically, mistakes made according to the Aboriginal people's pre-contact ethical code may have led to a Christian-style self-condemnation in a manner foreign to that code.

That Aboriginal Christians did alter their ideas about morality and often judged themselves as committing ethical breaches is evidenced in their letters to Mrs Ward. Bella Busch writes,

When I was naughty and in bad temper how you tell me that's not right for me to do, then you tell me about Jesus love, you taught me just like your own girl ... But your kindness never ceased from me when I go a stray and do things that's not right in our Saviour side. You always teach me what is right. Your talking always touch my heart and your saying a great feeling to me when you tell me of Jesus and his love ... How you bring my wandering soul back to the Shepherds fold. So I thank God that you are a servant of God ... Also I will remember all what you have taught me how to live a better life. ${ }^{27}$

Perhaps the clearest statement about how radical the shift in morality was comes 'out of the mouths of babes', from Annie, 'I hope to be a good girl and don't give any trouble and to obey every little thing even when I at school or at play' ${ }^{28}$ Annie gets to the heart of the matter in equating the good side of the newly introduced good-bad dichotomy with adoption of missionary values.

The dichotomised worldview the missionaries put forward undermined Aboriginal self-confidence and self-justification. Not only were the Aboriginal 
people taught that all people were sinners, but that Aboriginal people had fallen farther than the rest of humanity. In many of their letters to Mrs Ward, Aboriginal people wrote about being good with God's help or the missionaries' prayers. Many accepted their need for moral improvement; some even doubted their ability to do this without the help of God or the missionaries. They became so fixated on God's power that they rested their own futures on it rather than themselves. In his letter to Mrs Ward, Alexander asks her to keep in touch so they know how she is 'But I'll leave it all to Jesus he knows what is best for you and I' ${ }^{29}$ The adoption of Christianity to assuage feelings of guilt created more guilt, which of course increased the usefulness of Christianity to alleviate these feelings.

\section{The cycle begins again}

It is not surprising that Aboriginal Christians sought to alleviate the feelings of guilt and inadequacy they felt. The social conditions at the mission and particularities about Moravian Christianity meant that many did so by spreading Christianity to others and beginning the cycle again.

The social conditions that saw those spreading the Word in a superior position to those to whom it was being spread was an inducement to join the ranks of the former. Many missionaries, including the pioneer missionaries at Mapoon, often saw their work as never finished because they believed the faith of the newly converted was still fragile and needed protection from someone with stronger faith, the missionary. It takes little imagination to envision at least some of the ways in which ideas of racial and cultural superiority complemented this view. The perspective from the other side of the missionary experience at Mapoon - that of the newly converted - was very different. The people who accepted more or less of the Christian story were aware that those who brought them the Gospel did not feel most of them had developed or were responsible enough to be left alone with it, furthering the already strong feelings of guilt and inadequacy discussed above. From the European Christian perspective at Mapoon, missionaries were always the powerful, knowledgeable, generous ones giving of themselves and spreading the Word while Aboriginal people were, initially at least, not seen by the missionaries as having anything of spiritual value to share. With time, Aboriginal people sought and found ways to become givers and share the Word themselves. The hierarchy of savers and saved the missionaries brought also meant that by becoming givers in this relationship, they were simultaneously moving up the moral ladder. Spreading their faith both alleviated the guilt and increased the social status of Aboriginal Christians at Mapoon.

This degree to which sharing the Gospel was a liberating and empowering activity was especially true at Moravian missions. One of the Moravian Church's distinguishing features is its emphasis on missionary work. ${ }^{30}$ Missionary work 
was a task always before devout Moravians whether or not they were venturing into the mission fields themselves. Even marriage was viewed as an opportunity to help a member of the opposite sex improve their relationship with God. One consequence of the importance placed on missionary work was the high social and spiritual status accorded to missionaries among Moravians. ${ }^{31}$

Aboriginal Christians at Mapoon realised the liberating effects that spreading, rather than just receiving, Christianity could have. It was not long after a Christian community had formed among Aboriginal people at Mapoon that Aboriginal Christians began to work to assist in other Christian pursuits. Older Aboriginal people built a church and helped support a Christian teacher for Aboriginal people. Younger Christians made crafts in an effort to contribute to other missions and the Red Cross. ${ }^{32}$

Some Aboriginal people at Mapoon went to help convert other Aboriginal people elsewhere in Australia. In a 1918 report, Nicholas Hey wrote,

The great event of the year was the marriage of 5 couples on June 19, two of whom left the following day to join the staff of the Wesleyan Aboriginal Mission at Goulburn Island Northern Territory. A third couple is prepared to go to Mornington Island if required \& a fourth couple will be married shortly \& proceed to Weipa to assist Mr. \& Mrs Hall. We felt sorry to lose such promising workers, yet we rejoice also that we had the honour to send forth missionaries from our midst. ${ }^{33}$

Through these activities, Aboriginal people helped shape other people's religious views as the European missionaries had helped shape their own. Working for Christian causes allowed Aboriginal people to become active participants in part of a worldwide network labouring for God. This investment of time and money would have helped cement people's faith. Further, those who contributed time or money to the greater Christian cause would be repaid in additional pride, a resource that was often scarce at settler institutions for Aboriginal people. Such activities also would have probably been the most effective way for Aboriginal people to palliate their new burdens of guilt.

\section{Conclusions}

The passing of guilt along with Christian faith began well before the first missionaries came to Cape York Peninsula and continued after their departure. The period of time examined in this article, however, is uniquely important because it gives particular emphasis to the question of power in the process of spiritual change and because it sheds light on several important areas of the history of missions. The story sheds light on some hitherto understudied ways in which Aboriginal people made Christianity their own. It provides an exception to the general rule that Aboriginal people do not convert to Christianity or take up a European-Christian worldview if there is any semblance of the traditional 
social structure remaining. This, in turn, points to the psychological function of spirituality for Aboriginal Australians at the time of contact. Finally, it helps explain the remarkable success Moravian missionaries have had in their missions.

The field of Aboriginal studies currently gives great weight to the previously neglected task of identifying how Aboriginal people shaped the frontier. In this context, the question 'Were Aboriginal people creative actors in becoming Christian?' must be asked, because despite the earlier comparison, an Aboriginal person using Christianity to meet psychological needs is not exactly the same as using a metal knife to skin a kangaroo. For at least two reasons, the answer has to be 'yes'.

Much ink has been used by social scientists trying to discover the determinants of religious change and conversion. While little agreement exists, most hypotheses suggest that religion meets (usually unconscious) psychological needs and that spiritual change is an attempt to satisfy these needs. ${ }^{34}$ Even among theorists who emphasise social factors as important in religious changes, these alterations in beliefs and practices are seen as meeting individual needs or arising from individual agency, ${ }^{35}$ though some have noted conversion is socially defined $^{36}$ and that the change in religious designation does not come from the convert. $^{37}$ Seen in this light, conversion is at base an individual act, even if it not one over which people have conscious control. So using Christianity to assuage feelings of guilt differs from using a metal knife to skin a kangaroo in that it is not consciously employed, but both are employed by individuals to meet those individuals' needs.

The adoption of Christian beliefs differs from the use of a metal knife also in that it is far more creative because it requires much more modification of and integration with other beliefs and practices. The amount of integration required in everyday life would have made it impossible for Aboriginal individuals not to be creative in their understanding and expression of these beliefs. The comparison between the use of Christianity and a metal knife is useful in its emphasis that when Aboriginal people adopted Christian beliefs at Mapoon, they were not merely imitating Europeans. They were using all of the spiritual material at their disposal to make emotional sense of their world.

There is a second reason that Aboriginal Christians must be seen as actively shaping their own faith: the Christian perspective the missionaries brought and Aboriginal Christians more or less adopted emphasised that conversion and religious change were primarily individual acts. While no one would deny that the missionaries were a necessary condition for Aboriginal people becoming Christian, people at Mapoon probably would have argued that their presence was not a sufficient condition. This Protestant Christian viewpoint emphasises nothing if not a one-on-one relationship with God, even if it allows one to ask for others' prayers for strengthening one's faith. The importance of individual 
responsibility was the heart of the realisation Nicholas Hey made in Europe when he decided to read 'his Bible systematically, in the hope that some good might come of it'. ${ }^{38}$ This Christianity sees conversion as the quintessential creative act. People are reborn: Saul became Paul. Aboriginal Christians at Mapoon may have felt terribly indebted to the missionaries for bringing them Christianity, but certainly thought that their own beliefs were largely their own responsibility, even if God's help was required.

The story of Christianity and guilt at Mapoon is especially interesting because it provides an exception to the general rule that Aboriginal people adopt Christianity only when their traditional social structures have been decimated. ${ }^{39}$ Resistance to becoming Christian is seen even when Aboriginal people have incorporated Christian stories and personages, such as Noah and Jesus, into their spiritual landscapes. ${ }^{40}$ Aram A. Yengoyan argues that Aboriginal people adopted Christian beliefs and practices in a significant way only in conditions of 'economic need or social deprivation or both. In such examples, the tribal ethic or structure has been destroyed with much of the Aboriginal population' ${ }^{41}$ According to Yengoyan, it is impossible to change directly from traditional spirituality to Christianity because of the 'prior text' in traditional spirituality, which does not allow people to make the switch.

The mission at Mapoon under the co-leadership of the Hey and Ward families, however, is remarkable for the number of people who adopted Christian beliefs. In 1891, when the Moravian missionaries first arrived at what would become Mapoon mission on the western coast of Cape York, most of the Aboriginal people were totally unexposed to the Christian notion of sin. Less than 30 years later, sin occupied a prominent place in the intellectual and emotional life of the Aboriginal people at Mapoon. Yengoyan's criteria for Aboriginal adoption of Christianity do not seem to have been met at Mapoon. It is difficult to determine how much of the 'tribal ethic or structure' had 'been destroyed' prior to the missionaries' arrival, given the lack of recordings of European contact with Aboriginal people there. Nevertheless, with the possible exception of some Aboriginal people who came to the mission from other places, it does not seem to have been the sort of massive devastation Yengoyan has in mind. ${ }^{42}$ After the missionaries arrived, devastation does not seem to have occurred at Mapoon on anywhere near the scale as in many other missions which were less successful at promulgating Christianity. 43

It would not do to give the impression that every Aboriginal person at Mapoon adopted Christianity, nor would it be appropriate to deny that factors other than guilt might have influenced Aboriginal people's changes toward Christianity. Some Aboriginal people at Mapoon, mostly older ones, did not accept Christianity. This was true for a number of reasons, not least because they were emotionally and socially invested in traditional spirituality. Additionally, they 
had less contact with missionaries, who actively divided the Aboriginal population into Christians and pagans. After a certain point, the missionaries were reluctant to expend their resources attempting to convert these older Aboriginal people and concentrated their efforts on younger Aboriginal people. It is also reasonable to assume that some younger Aboriginal people simply left the area. Beyond these non-converts, the Aboriginal people who were regarded by themselves and by the missionaries as Christians did not fully accept every aspect of the Christianity the missionaries brought. They modified Christianity and made it their own; all converted populations do. What is remarkable is how much of the missionaries' Christianity they accepted with so little modification in so short a time.

Other factors guided the population toward Christianity. The dormitory system probably impeded Aboriginal cultural transmission. Immigration of Aboriginal people from other groups may have increased spiritual tensions and threats while the immigrants themselves were probably spiritually homesick, both problems that Christianity may have been able to help alleviate. ${ }^{44}$ While each of these factors was important, there were a number of missions in Australia where they were replicated and Aboriginal people have still been much more reluctant to accept the Christian ideas. Since these factors are not unique to Mapoon, they cannot be used to explain why so many people at this Moravian mission adopted Christianity and the Christian view of moral transgression when so few Aboriginal people at many other missions did. In this paper I have argued that the notable degree and rapid pace of the adoption of Christianity was due largely to importance the missionaries placed on the emotion of guilt and the way in which Christianity's notion of transgression helped make sense of and give meaning to this emotion.

The time period at Mapoon examined in this article also helps explain why the Moravian Church has had such success in its missionary work. The Moravian Church has long placed an emphasis on missionary work. It has devoted a very high proportion of its resources to setting up a number of missions far exceeding that which would be expected of so small a denomination. ${ }^{45}$ What is most remarkable, however, is the success these missions have had in Christianising people who have been resistant to spiritual change. ${ }^{46}$ One might hypothesise that Yengoyan's thesis that the 'prior text' of a group's spirituality can inhibit Christianisation if its values and view of the universe are very different from Christianity holds true for groups outside Australia as well, and that Moravian missionaries often find some way to get around this.

As discussed above, guilt played a major role in the emotional and spiritual lives of most Moravians. ${ }^{47}$ It is notable that while there is no single blueprint for how Moravian missions should be run, missionaries were instructed not to talk too much about God or the trinity but instead focus on Christ's suffering and 
forgiveness. ${ }^{48}$ These emphases imply an understanding of, and preoccupation with, sin. Perhaps the Moravians' success as missionaries is explained by, and therefore supports, the hypothesis that the creation of guilt in a population can dramatically increase its probability of adopting Christian beliefs and practices. This is especially true where the 'prior text' of the population's spirituality makes it resistant to other methods of spreading Christianity by focusing on balance rather than hierarchy, on interrelations and reciprocity rather than debt and guilt.

As an exception to Yengoyan's rule, Mapoon's population points to a primary cause of spiritual change during colonisation and, beyond that, to a fundamental role of spirituality in Aboriginal life during colonisation. The population at Mapoon underwent massive changes to its material way of life, but so did many other Aboriginal populations that did not undergo a shift in spirituality toward Christianity. Aboriginal spirituality must not have been a mere reflection of material life or just an intellectual tool used to cope with the major social and ecological changes taking place.

Spirituality gave meaning to and made sense of the emotional landscape of individual Aboriginal people. The violence and dispossession of colonisation mostly did not require Christianisation because traditional spirituality could usually meet the demands this made on Aboriginal people without drastic modifications. Colonisation was a massive disruption to equilibrium, and therefore within the purview of traditional spirituality. The guilt experienced by many Aboriginal people at Mapoon, however, was not. Guilt implies both a degree of hierarchy and a dichotomy between good and evil not found in traditional Aboriginal spirituality. Many Aboriginal people at Mapoon, therefore, adopted much of the missionaries' Christianity and its understanding of and emphasis on transgression in an effort to locate and give meaning to new feelings of guilt.

\section{References}

\section{Primary sources}

Records of Mapoon and Weipa 1893-1967, MF 305, Presbyterian Church of Australia, Board of Ecumenical Mission and Relations, Australian Institute of Aboriginal and Torres Strait Islander Studies.

\section{Secondary sources}

Combs-Bowles, Devin 2004, 'Southern Crossroads to Damascus: Christianities at three Australian Missions', MA thesis, The Australian National University. 
Ferry, John 1979, 'The Failure of New South Wales Missions to the Aborigines Before 1845', Aboriginal History 3(1): 25-36.

Geertz, Richard 1966, 'Religion as a Cultural System', in M Banton (ed.), Anthropological Approaches to the Study of Religion, Tavistock Publications, London.

Gollin, Gillian Lindt 1967, Moravians in Two Worlds: a study of changing communities, Columbia University Press, New York.

Gunson, Niel (ed.) 1974, Australian reminiscences and papers of LE Threlkeld, missionary to the Aborigines, 1824-1859 (2 vols), Australian Institute of Aboriginal Studies, Canberra.

Hefner, Robert W 1993, 'On Faith and Commitment: Christian conversion in Muslim Java', in Robert W Hefner (ed.), Conversion to Christianity: historical and anthropological perspectives on a great transformation, University of California Press, Berkeley.

Hey, Rev. JN 1931a, A Brief History of the Presbyterian Church's Mission Enterprise among the Australian Aborigines, New Press, Sydney.

1931b, The Moravian Church: (Unitas Fratrum), or the Unity of Brethren, J.N. Hey, Sydney.

Horton, Robin 1971, 'African Conversion', Africa 41(3): 85-108.

— 1975a, 'On the Rationality of Conversion', part 1, Africa 45(3): 219-235.

— 1975b, 'On the Rationality of Conversion', part 2, Africa 45(4): 373-399.

Lampe, Armando 2001, Mission or Submission? Moravian and Catholic Missionaries in the Dutch Caribbean during the 19th century, Vandenhoeck \& Ruprecht, Göttingen.

Lewis, AJ 1962, Zinzendorf the Ecumenical Pioneer A Study in the Moravian Contribution of Christian Mission and Unity, SCM Press Ltd, London.

Lofland, John and Rodney Stark 1965, 'Becoming a World-Saver: a theory of conversion to a deviant perspective', American Sociological Review 30(6): 862-75.

MacIntyre, Ronald G 1931, 'Foreword', in JN Hey (author), The Moravian Church: (Unitas Fratrum), or the Unity of Brethren, J.N. Hey, Sydney.

McDonald, Heather 2001, Blood, Bones, and Spirit: Aboriginal Christianity in an East Kimberley town, Melbourne University Press, Carlton South.

Merrill, William L 1993, 'Conversion and Colonialism in Northern Mexico: the Tarahumara response to the Jesuit mission program, 1601-1767', in Robert W Hefner (ed.), Conversion to Christianity: historical and anthro- 
pological perspectives on a great transformation. University of California Press, Berkeley.

Murphy, William P 1981, 'The Rhetorical Management of Dangerous Knowledge in Kpelle Brokerage', American Ethnologist 8(4): 667-685.

Ng, Kwai Hang 2002, 'Seeking the Christian Tutelage: agency and culture in Chinese immigrants' conversion to Christianity', Sociology of Religion 63(2): 195-214.

Pollock, Donald K 1993, 'Conversion and "Community" in Amazonia', in Robert W Hefner (ed.), Conversion to Christianity: historical and anthropological perspectives on a great transformation, University of California Press, Berkeley.

Rose, Deborah Bird 1988, 'Jesus and the Dingo', in T Swain and D Rose (eds), Aboriginal Australians and Christian Missions, Australian Association for the Study of Religion, Bedford Park: 361-375.

_ 1992, Dingo Makes Us Human: life and land in an Australian Aboriginal culture, Cambridge University Press, Cambridge.

1994, 'Ned Kelly Died for our Sins', Oceania 65: 175-186.

Sharp, Nonie 1992, Footprints Along the Cape York Sandbeaches, Aboriginal Studies Press: Canberra.

Ward, Arthur 1908, The Miracle of Mapoon, or, From Native Camp to Christian Village, S. W. Partridge \& Co, London.

Yang, Fenggang 1998, 'Chinese Conversion to Evangelical Christianity: the importance of social and cultural contexts', Sociology of Religion 59(3): 237257.

Yengoyan, Aram, A 1993, 'Religion, Morality, and Prophetic Traditions: conversion among the Pitjantjatjara of central Australia', in Robert W Hefner (ed.), Conversion to Christianity: historical and anthropological perspectives on a great transformation, University of California Press, Berkeley.

\section{ENDNOTES}

\footnotetext{
1 See generally McDonald 2001.

2 See generally Rose 1992 especially chapter 11.

3 Hey 1931a: 10.

4 Ward 1908: 35-42.

5 Ward 1908: 36-7.

6 Ward 1908: 37.

7 Ward 1908: 37-8.

8 Ward 1908: 41.

9 Ward 1908: 41-2.

10 See generally Ward 1908.
} 
${ }^{11}$ See generally Records of Mapoon and Weipa: 1893-1967 Reel 2. The author of the diary may be Mrs Ward, but it is not certain.

${ }^{12}$ Hey 1931a: 10.

13 Hey 1931a: 10-11.

14 Records of Mapoon and Weipa Reel 2: 50.

15 Records of Mapoon and Weipa Reel 2: 50.

16 Records of Mapoon and Weipa Reel 2: 554.

17 Records of Mapoon and Weipa Reel 2: 564.

18 Records of Mapoon and Weipa Reel 2: 561.

19 Records of Mapoon and Weipa Reel 2: 600.

20 Records of Mapoon and Weipa Reel 2: 557.

${ }^{21}$ Gollin 1967: 11.

22 Records of Mapoon and Weipa Reel 2: 571.

${ }^{23}$ Records of Mapoon and Weipa Reel 2: 571-2.

24 Records of Mapoon and Weipa Reel 2: 588.

25 Records of Mapoon and WeipaReel 2: 558.

26 See Murphy 1981 for a discussion of brokers as mediating between people and the supernatural.

27 Records of Mapoon and Weipa Reel 2: 596-7.

28 Records of Mapoon and Weipa Reel 2: 580.

29 Records of Mapoon and Weipa Reel 2: 576.

30 See generally Gollin 1967; MacIntyre 1931.

31 Gollin 1967: 97, 101, 200.

32 See generally Records of Mapoon and Weipa Reel 2.

33 Records of Mapoon and Weipa Reel 2: 84.

34 See generally Geertz 1966; Horton 1971, 1975a, 1975b; Lofland and Stark 1965.

35 See generally Ng 2002; Yang 1998.

36 See generally Pollock 1993.

37 Merrill 1993: 153-4.

38 Ward 1908: 37.

39 See generally Ferry 1979; Yengoyan 1993.

40 See generally Rose 1988, 1992, 1994.

${ }^{41}$ Yengoyan 1993: 234.

42 See generally Records of Mapoon and Weipa; Sharp 1992.

43 See generally Combs-Bowles 2004; Ferry 1979; Gunson 1974; Yengoyan 1993.

44 Combs-Bowles 2004 chapter 4.

${ }^{45}$ See generally Gollin 1967.

46 Lewis 1962 chapter 5; see generally Hey 1931b.

47 See generally Gollin 1967.

${ }^{48}$ Lampe 2001: 37. 